\title{
Harmoni Sosial: Jurnal Pendidikan IPS \\ PENDIDIKAN MULTI KULTURAL BERBASIS KEARIFAN LOKAL (STUDI DI SMA NEGERI 1 NARMADA)
}

\author{
Zainul Muttaqin ${ }^{1 *}$, Amika Wardana ${ }^{1}$ \\ ${ }^{1}$ Universitas Negeri Yogyakarta \\ ${ }^{1} \mathrm{Jl}$. Colombo No. 1, Depok, Sleman 55281, Yogyakarta, Indonesia \\ * Corresponding Author. Email: zainulyong74@gmail.com
}

\begin{abstract}
Abstrak
Penulisan artikel ini bagian dari master tesis yang bertujuan untuk mendeskripsikan bagian dari pendidikan multikultural berbasis kearifan lokal sebagaimana dipraktikan di SMA N 1 Narmada, Lombok Barat, Nusa Tenggara Barat. Penelitian ini menggunakan pendekatan kualitativ. Subyek dalam penelitian ini adalah kepala sekola, guru, siswa dan staf non-akademik lainya yang ada di lingkugan sekolah. hasil penelitian ini menunjukan 4 (empat) temuan utama: (1) imtaq dan kegiatan peduli sosial (wales/bales) sebagai nilai utama dari pendidikan multikultural berbasis kearifan lokal; (2) Alam takambang jari guru as mode pembelajaran; (3) gendang baleq sebagai bagian dari pendidikan multikultural berbasis kearifan lokal bertujuan untuk menanamkan nilai-nilai harmonisasi dalam perbedaan; (4) kultur sekolah sebagai pondasi proses sosialisasi dan internalisasi nilai-nilai multikultural berbasis kearifan lokal.
\end{abstract}

Kata Kunci: pendidikan multikultural, kearifan lokal.

\section{MULTICULTURAL EDUCATION BASED ON LOCAL WISDOM (STUDY AT STATE SENIOR HIGH SCHOOL 1 IN NARMADA)}

\begin{abstract}
The article written as part of master thesis-aimed to investigate the forms of the multicultural education based on local wisdom as it practiced at State Senior High School 1 in Narmada, West Lombok. The study was pursued under the qualitative approach. The subject of the research is Headmaster, teacher, students and other non-academic staffs of the school. The research result 4 (four) main findings: (1) Imtaq and social care activities (wales/bales) as the fundamental values of multicultural education based on the local wisdom; (2) Alam Takambang Jari Guru as learning model; (3) Gendang Beleq as a form of multicultural education based on the local wisdom as an attempt of harmonization of togetherness in difference; (4) school culture is the basic foundation of the socialization and internalization process of multicultural education based on the local wisdom. Keywords: multicultural education, local wisdom,
\end{abstract}




\section{Pendahuluan}

Pendidikan multikultural pada dasarnya memberikan kemerdekaan bagi kaum minoritas. Kemerdekaan itu harus dirasakan bersama-sama tanpa ada diskriminasi. Sebagaimana yang dikatakan oleh tokoh pendidikan Indonesia Dewantara (2013, pp. 3-4), Pendidikan merupakan peroses memerdekakan manusia, dan manusia yang merdeka adalah manusia yang secara lahir dan batinnya tidak tergantung kepada orang lain, akan tetapi bersandar atas kekuatan sendiri. Kehidupan manusia yang merdeka itu adalah mereka yang bebas dari penindasan serta ketidakadilan, kemudian hidup bersama-sama dengan orang lain dan memiliki hak yang sama untuk merasakan kemerdekaan itu. Selanjutnya prinsip penyelenggaraan pendidikan secara jelas juga telah diuraikan dalam Undang-Undang Republik Indonesia Nomor 20 Tahun 2003 tentang Sistem Pendidikan Nasional (Presiden Republik Indonesia, 2003), yang tercantum pada pasal 4 bahwa pendidikan diselenggarakan secara demokratis dan berkeadilan serta tidak diskriminatif dengan mejunjung tinggi hak asasi manusia, nilai keagamaan, nilai kultural, dan kemajemukan bangsa.

Oleh karena itu, pendidikan multikultural didesain untuk membangun serta memberikan rasa keadilan, juga memberikan gambaran ideal tentang keberagaman melalui proses belajar mengajar, karena pendidikan multikultural sebagaimana yang dijelaskan oleh Zamroni (2013, p. 26), merupakan suatu bentuk reformasi pendidikan yang bertujuan untuk memberikan kesempatan yang setara (adil) bagi semua siswa tanpa memandang latar belakangnya. Di sisi lain, Mahfud (2014, p. viii) melihat dari aspek kehidupan bahwa pendidikan multikultural itu dapat dirumuskan sebagai wujud kesadaran tentang keanekaragaman kultural, hak-hak asasi manusia serta pengurangan atau penghapusan berbagai jenis prasangka (prejudice) untuk membangun suatu masyarakat yang adil dan maju. Maka pendidikan multikultural adalah salah satu pendekatan yang sesuai untuk masyarakat Indonesia yang majemuk, heterogen, begitu juga halnya di SMA Negeri 1 Narmada, yang mempunyai siswa dari latar belakang yang berbeda-beda.

Namun pada kenyataannya pendidikan multikultural hanya sebatas matapelajaran yang tidak banyak mengajarkan sebagai mata pelajaran di sekolah maupun di perguruan tinggi Hal ini dibuktikan dari penelitiannya Zuriyah (2011, pp. 79-80) bahwa kebanyakan guru maupun dosen melihat siswa sebagai objek, menyampaikan pelajaran tanpa mau dikritisi. Selanjutnya Dosen tidak dapat meyakinkan mahasiswa untuk belajar dengan lebih bergairah, menarik dan bersungguh-sungguh, karena mahasiswa kurang dan bahkan tidak pernah dibelajarkan untuk berpikir kritis dan membangun konseptualisasi secara mandiri.

Disisi lain, beberapa hasil penelitian menunjukkan bahwa pendidikan multikultural memberikan kontribusi yang signifikan terhadap pengurangan diskriminasi dan konflik baik di lingkungan sekolah maupun masyarakat. Seperti yang dikatakan oleh Syahid (2013, pp. 129-130) dalam temuannya bahwa perencanaan pembelajaran berwawasan multikultural di sekolah sudah dilakukan dengan baik, dilihat dari penilaian aspek seluruh indikatornya. Pelaksanaan pembelajaran berwawasan multikultural dengan seluruh aspek indikatornya telah memberikan kontribusi bagi siswa khususnya, antara lain adanya perubahan suasana belajar di kelas, suasana belajar menjadi lebih menyenangkan bagi siswa, selain itu ada yel-yel sebelum dan sesudah pembelajaran. Oleh karena itu, dampak pendidikan multikultural sangat signifikan, seperti; harmoni diri, harmoni sesama, harmoni alam, dan model pembelajaran multikultural dilakukan secara kontekstual dengan menggali dan memperkuat kearifan lokal, baik nilai-nilai sosial budaya maupun kekayaan alam hayati, dengan tetap mendukung pencapaian standar kompetensi dasar yang telah ditetapkan.

Selanjutnya, Arifudin (2007, p.2-8) menjelaskan bahwa pendidikan multikultural tidak harus berdiri sendiri, tetapi dapat terintegrasi dalam mata pelajaran dan proses pendidikan yang ada di sekolah termasuk keteladanan para guru dan orang-orang dewasa di sekolah. Oleh karena itu, pendidikan multikultural haruslah mencakup hal yang berkaitan dengan toleransi, perbedaan etno-kultural dan agama, bahaya diskriminasi, penyelesaian konflik dan mediasi, serta pendidikan multikultural harus diimplementasikan berupa tindakan-tindakan, baik di sekolah maupun di masyarakat.

Sedangkan Arifin (2012) mengatakan bahwa pendidikan multikultural di Indonesia masih menjadi wacana baru yang perlu dires- 
pon untuk menjaga keutuhan bangsa yang kaya akan multikultur, juga pendidikan multikultural merupakan wujud kesadaran tentang keanekaragaman kultural, hak-hak asasi manusia serta pengurangan atau penghapusan jenis prasangka (prejudice) untuk suatu kehidupan masyarakat yang adil dan maju. Selain itu, dalam menghadapi pluralisme budaya, diperlukan paradigma baru yang lebih toleran dan elegan untuk mencegah dan memecahkan masalah benturan-benturan budaya tersebut, Oleh karenanya praktik pendidikan multikultural di Indonesia dapat dilaksanakan secara fleksibel dengan mengutamakan prinsip-prinsip dasar multikultural. Pendidikan multikultural juga sangat relevan dengan pendidikan demokrasi di masyarakat plural seperti Indonesia, yang menekankan pada pemahaman akan multi etnis, ras, dan multikultur yang memerlukan konstruksi baru atas keadilan, kesetaraan, dan masyarakat yang demoktratis.

Berbagai model pendidikan multikultural yang sudah diterapkan dalam mengantisipasi terjadinya diskriminasi dan konflik di linkungan sekolah maupun di lingkungan sosial masyarakat, masih belum menemukan titik terang. Artinya bahwa masih ada diskriminasi serta ketidakadilan yang terjadi di lingkungan sekolah. Selain itu, kearifan lokal yang seharusnya dijadikan basis dalam membangun perspektif tentang pendidikan multikultural, masih sedikit, kalaupun ada, kebanyakan bukan mengenai pendidikan multikultural. Seperti penelitian yang dilakukan Dasrun (2013, pp. 1058-1060) tentang "permainan tradisional dan kearifan lokal Kampung Dukuh Garut Selatan Jawa Barat" yang melihat fokus kajian prihal nilai-nilai kearifan lokal dalam sebuah permainan dengan hasil bahwa warga Kampung Adat Dukuh masih menanamkan konsep dasar permainan konclong dari generasi ke generasi. Orangtua maupun anak-anak memahami nilai-nilai kearifan lokal yang terkandung pada permainan tradisional konclong meliputi nilai motorik, kognitif dan nilai moral yang perlu dilestarikan dan tidak pada aspek pendidikan multikultural. Selain itu, Qodariah \& Armiyati (2013 p.19-20) juga melihat "nilainilai lokal masyarakat adat Kampung Naga sebagai alternatif sumber belajar IPS di Tasikmalaya" dengan melihat sejarah dan karakteristik kearifan lokal masyarakat tersebut, serta memperoleh nilai-nilai kearifan lokal yang dapat diintegrasikan dalam mata pelajaran IPS.

Sedangkan Soedigdo, Harysakti, \& Usop (2014, pp. 37-45) melihat "elemen-elemen pendorong kearifan lokal pada arsitektur nusantara" yang hanya memfokuskan penelitiannya dengan melihat elemen-elemen yang mendorong timbulnya kearifan lokal dalam arsitektur di nusantara. Selanjutnya menemukan hasil bahwa elemen pendorong timbulnya suatu kearifan lokal adalah elemen manusia beserta pola pikirannya, dan elemen alam beserta iklimnya, Sedangkan di Lombok Barat sendiri menggunakan kearifan lokal sebagai seperangkat alat untuk merekatkan hubungan antara suku sasak Muslim dangan dengan umat Hindu di desa Lingsang Lombok Barat NTB (Ahmad, 2010, pp. 187-198).

Berdasarkan hasil prasurvei pada siswa SMA Negeri 1 Narmada Kabupaten Lombok Barat, bahwa sikap kritis siswa terhadap realitas keragaman dalam masyarakat dibangun baik di dalam kelas, luar kelas serta di tengah masyarakat. Di dalam dan luar kelas (masih dalam konteks sekolah) siswa diminta untuk menganalisis atau menggambarkan keragaman yang ada dari berbagai sudut pandang. Misalnya, dalam sudut pandang agama, sosial, budaya ataupun politik, karena analisis keragaman tersebut merupakan upaya untuk menerapkan pendekatan kontekstual dalam pembelajaran di kelas. Sebab, fenomena itulah yang banyak terjadi di seputar wilayah Narmada pada khususnya bahkan Indonesia pada umumnya.

Dari uraian tersebut, jelas bahwa pendidikan multikultural sebagai sumber belajar di dalam mengurangi berbagai bentuk diskriminasi, konflik, dan lain sebagainya telah dilakukan. Begitupun kearifan lokal sebagai sumber belajar di sekolah sudah dilakukan oleh beberapa peneliti, namun belum ada yang meneliti tentang pendidikan multikultur yang menggunakan kearifan lokal sebagai sumber belajar untuk diintegrasikan ke dalam mata pelajaran yang berkaitan dengan multikulturalisme itu sendiri. Dengan alasan itulah, maka peneliti merasa tertarik untuk melakukan penelitian tentang pendidikan multikultural berbasis pada kearifan lokal (local wisdom) dengan peserta didik yang memiliki beragam etnis, bahasa, serta agama yang rentan dengan prasangka dan diskriminasi bahkan berujung konflik. 
Berdasarkan latar belakang dan identifikasi masalah di atas, maka penelitian ini dibatasi pada satu sekolah yaitu, SMA Negeri 1 Narmada Kabupaten Lombok Barat dengan judul pendidikan multikulutral berbasis kearifan lokal. Selanjutnya rumusan masalah dalam penelitian ini adalah bagaimana bentuk pendidikan multikultural berbasis kearifan lokal di SMA Negeri 1 Narmada Kabupaten Lombok Barat serta bagaimana proses sosialisasi dan internalisasi pendidikan multikultural berbasis kearifan lokal di SMA Negeri 1 Narmada Kabupaten Lombok Barat.

\section{Metode Penelitian}

Penelitian ini menggunakan jenis penelitian kualitatif. Penelitian ini tidak dimaksudkan untuk memberikan perlakuan pada subjek yang diteliti, tetapi hanya mengamati, mengkaji, dan menelaah hal-hal yang dilakukan oleh subjek yang diteliti dalam melakukan kegiatan pembelajaran sehari-hari, baik yang dilakukan oleh guru maupun reaksi dan sikap siswa selama berlangsungnya kegiatan pembelajaran. Kegiatan pembelajaran tersebut merupakan perilaku sosial sehari-hari yang dilakukan oleh guru dan siswa. Oleh karena itu, dalam penelitian ini peneliti berusaha mengungkap suatu fenomena sosial yang terjadi khususnya kegiatan-kegiatan yang terjadi di lingkungan sekolah SMA Negeri 1.

Setting penelitian ini meliputi tiga dimensi yaitu; dimensi tempat, dimensi pelaku, dan dimensi kegiatan. Kaitannya dengan apa yang diungkapkan di atas maka peneliti menetapkan setting tempat penelitian di SMA Negeri 1 Narmada yang terletak di desa Narmada kecamatan Narmada Kabupaten Lombok Barat Propinsi Nusa Tenggara Barat. Lokasi sekolah di pinggir jalan tepatnya di tengah-tengah antara desa Lingsar dengan desa Narmada. Pada desa lingsar mayoritas penduduknaya beragama Hindu sedangkan di desa Narmada mayoritas beragama Islam, sehingga lokasi sekolah sangat strategis untuk dua desa yang berbeda secara keyakinan.

Setting pelaku dalam penelitian ini adalah semua pihak yang terlibat dalam pelaksanaan pendidikan multikultural yang besumber pada niai-nilai lokal yaitu, seperti kepala sekolah sebagai pimpinan tertinggi di sekolah serta guru, dan yang paling penting adalah siswa yang ada di SMA Negeri 1 Narmada. Selan- jutnya Setting kegiatan antara lain meliputi kegiatan ekstrakulikuler, kegiatan yang peneliti lakukan yaitu, mengikuti kegiatan yang ada di sekolah SMA Negeri 1 Narmada seperti rapat koordinasi, kegiatan administrasi, kegitan kurikulum dan pembelajaran serta kegiatan kegiatan yang mendukung bagi peneliti.

Unit analisis yang menjadi sasaran dalam peneltian ini adalah kepala sekolah, guru, siswa, serta semua elemen yang ada di dalam lingkungan sekolah SMA Negeri 1 Narmada. Selanjutnya memilih informan dengan menggunakan Purposive sampling, sehingga dapat menampung semua informasi dari berbagai sumber. Pemilihan informan menggunakan teknik purposive sampling bertujuan agar peneliti mendapatkan data yang mendalam dan relevan dengan subjek penelitian. Selanjutnya kreteria Purposive sampling menurut Moleong (2007, p. 57) bahwa sampel tidak dapat ditentukan terlebih dahulu, memilih sampel secara berurutan, sampel dipilih atas dasar fokus penelitian, dan yang terakhir mempertimbangkan informasi-informasi yang ada. Akan tetapi ketika tidak ada lagi informasi yang dapat dijaring, maka pengambilan sampel sudah dapat diakhiri. Oleh karena itu, dalam penelitian ini peneliti mencari informan yang memenuhi kriteria

Sumber data dalam penelitian ini yaitu kepala sekolah, guru, dan yang paling penting adalah siswa untuk menggali lebih secara mendalam tentang proses pendidikan multikultural berbasis kearifan lokal serta bentuknya seperti apa. Selain itu, beberapa sumber lainnya seperti staf dalam hal ini adalah bagian tata usaha (TU) Sedangkan teknik dan instrument dalam penelitian dengan melihat, mengamati kondisi alamiah (natural setting), sumber data primer, dan teknik pengumpulan data lebih banyak pada observasi berperan serta (particifan observation), wawancara mendalam dan dokumentasi (Sugiyono, 2013,p. 309).

Berikut penjelasannya yaitu, observasi, dalam hal ini, peneliti terjun langsung ke lokasi penelitian dan ikut berpartisipasi dalam kegiatan yang terjadi di lingkungan sekolah sambil melakukan pengamatan. Akan tetapi pada saat ada kegiatan yang dilakukan oleh siswa peneliti memberhentikan pengamatan karena berbagai pertimbangan yang menimbulkan dampak seperti mengganggu kegiatan tersebut, sehingga peneliti mengamati dari kejauhan. Bentuk-bentuk kegiatan yang peneliti 
amati antara lain; (a) kegiatan di dalam kelas, seperti proses belajar mengajar, diskusi kelompok. (b) Kegiatan di luar kelas, seperti kegiatan ekstra kulikuler, dan kegiatan guru serta kepala sekolah pada saat berada di luar kelas.

Bentuk kegiatan yang diobservasi pada tahap proses belajar mengajar adalah bagaimana guru menyampaikan materi pelajaran menyangkut pendidikan multikultural berbasis kearifan lokal. Selanjutnya peneliti mengamati sejauhmana siswa memahami konsep-konsep pendidikan multikultural yang menggunakan kearifan lokal sebagai sumber belajar. Selain itu, peneliti juga mengamati mengenai nilai kearifan lokal atau wujud kearifan lokal seperti yang diintegrasikan dalam proses menyampaikan materi terkait pendidikan multikultural. Begitu juga dengan kegiatan diluar kelas. Dalam konteks di luar kelas, peneliti mengamati kegiatan siswa dengan guru ketika proses kegiatan imtaq berlangsung. Akan tetapi berhubungan dengan siswa yang beragam dari aspek agama agama, maka peneliti membagi waktu dalam melakukan proses pengamatan dalam hal ini peneliti mengikuti apabila diizinkan dan sebaliknya.

Selanjutnya bentuk wawancara terhadap informan dengan menggunakan pedoman wawancara yaitu membuat catatan tentang pokok-pokok pertanyaan yang sesuai dengan tujuan penelitian (Mantra, 2008). Berangkat dari pendapat tersebut, peneliti melakukan wawancara mendalam dengan dua cara; yaitu wawancara terstruktur, dengan wawancara tidak terstruktur. Wawancara terstruktur dibuat jenis pertanyaan tertulis yang ditujukan kepada TU (tata usaha), guru, kepala sekolah, serta siswa mengenai bentuk, proses sosialisasi, dan internalisasi pendidikan multikultural berbasis kearifan lokal yang ada di SMA Negeri 1 Narmada Kabupaten Lombok Barat. Berikut kisi-kisi wawancara yang digunakan dalam penelitian ini yang dirumuskan dalam rumusan masalah dan selanjutnya dijabarkan dalam bentuk pertanyaan.

1. Bagaimana bentuk pendidikan multikultural berbasis kearifan lokal di SMA Negeri 1 Narmada Kabupaten Lombok Barat?

a. Apa visi dan misi Sekolah SMA Negeri 1 Narmada Kabupaten Lombok Barat

b. Bagaimanakah kultur sekolah yang ada di SMA N 1 Narmada di lihat dari:
1. Jenis Kelamin

2. Agama

3. Suku/Ras

4. Tingkat Ekonomi

c. Bagaimanakah bentuk pendidikan berbasis kearifan lokal di SMA Negeri 1 Narmada Kabupaten Lombok Barat?

1. Perencanaan

2. Proses

3. Hasil Evaluasi

2. Bagaimana proses sosialisasi dan internalisasi nilai multikulturalisme berbasis kearifan lokal di SMA Negeri 1 Narmada Kabupaten Lombok Barat?

a. Bagamanakah proses sosialisasi nilainilai multikultural berbasis kearifan lokal di SMA Negeri 1 Narmada Kabupaten Lombok Barat?

b. Bagaimanakah proses internalisasi (Penerapan) nilai-nilai kearifan lokal di dalam pendidikan multikultural berbasis kearifan lokal di SMA Negeri

1 Narmada Kabupaten Lombok Barat?

c. Bagaimanakah proses internalisasi pendidikan multikultural berbasis kearifan lokal di SMA Negeri 1 Narmada Kabupaten Lombok Barat?

d. Apa saja yang menjadi faktor penghambat dan pendukung dalam proses sosialisasi dan internalisasi pendidikan multikultural berbasis kearifan lokal di SMA Negeri 1 Narmada Kabupaten Lombok Barat?

Selanjutnya wawancara tidak terstruktur sebagaimana yang dikatakan Mantra (2008), pokok-pokok yang dirumuskan atau pertanyaan-pertanyaan yang sudah dirumuskan tidak perlu ditanyakan secara berurutan, demikian pula pada penggunaan dan pemilihan kata untuk wawancara, maka dalam penelitian ini peneliti menggunakan bahasa sendiri agar lebih bebas dan tidak terpaku pada satu pertanyaan, sehingga memudahkan peneliti dalam menggali informasi yang lebih akurat dan bisa dipercaya. Oleh sebab itu, untuk menghindari biasnya data dari hasil wawancara maka peneliti tidak hanya memakai buku catatan, melainkan peneliti memakai alat bantu seperti rekaman, dan lain sebagainya. Adapun isi.

Bentuk wawancara yang dimaksud antara lain; (a) Menanyakan kurikulum yang ada di SMA Negeri 1 Narmada dengan meng- 
gali. Pertanyaan ini diajukan kepada wakakurikulum sebagai penanggung jawab atas kurikulum yang diterapkan di SMA Negeri 1 Narmada Kabupaten Lombok Barat. (b) peneliti menanyakan konsep pendidikan multikultural sebagai materi yang diintegrasikan ke dalam mata pelajaran serta nilai-nilai kearifan lokal yang digunakan sebagai sumber belajar, dalam hal ini kepala sekolah serta guru yang menjadi sasaran untuk mendapatkan informasi mengenai pendidikan multikultural berbasis kearifan lokal. Mengenai pertanyaan-pertanyaan yang lain disusun pada pedoman wawancara.

Setelah melakukan observasi dan wawancara peneliti mengambil beberapa dokumen yang terkait dengan tujuan penelitian seperti kurikulum sekolah. Selanjutnya peneliti meminta profil sekolah SMA Negeri 1 Narmada sebagai langkah awal untuk melihat kondisi sekolah tersebut, dan itu peneliti jadikan dokumen sebagai data pendukung. Data tersebut bisa dijadikan data analisis dokumentasi kaitannya dengan sekolah yang memiliki siswa yang beragam. Selain itu peneliti mengambil beberapa gambar kaitanya dengan proses belajar mengajar di dalam kelas, dan gambar lainnya yang mendukung penelitian dalam konteks pendidikan multikultural berbasis kearifan lokal, seperti kegiatan diskusi dalam dan luar kelas, kegiatan imtaq yang dilaksanakan sesuai dengan agama masing-masing serta kegiatankegiatan yang mendukung lainnya.

Pengecekan keabsahan data dalam penelitian ini melalui beberapa teknik. Teknik ini dimaksudkan untuk menemukan ciri-ciri dan unsur-unsur dalam situasi yang sangat relevan dengan persiapan dan isu yang sedang dicari kemudian memusatkan diri pada hal-hal tersebut secara rinci. Ketekunan pengamatan dapat mengahasilkan kedalaman data yang diperoleh. Untuk itu, peneliti melakukan pengamatan secara teliti dan rinci serta berkesinambungan terhadap fenomena-fenomena yang tampak. Adapun teknik yang dimaksud anatara lain:

Kredibilitas, yaitu data dan informasi yang dikumpulkan harus mengandung nilai kebenaran, artinya hasil penelitian kualitatif harus dapat dipercaya oleh para pembaca yang kritis dan dapat diterima oleh responden yang memberikan informasi yang dikumpulkan. Untuk mendapatkan itu semua dalam hal ini peneliti menggunakan pendekatan sosial terha- dap responden. Dengan demikian, responden tidak lagi ragu memberikan informasi yang sebenarnya karena antara peneliti dengan responden sudah merasa dekat dikarenakan keterbukaan dari peneliti.

Selnjutnya dependabilitas, yaitu untuk mengecek apakah hasil penelitian kualitatif bermutu atau tidak, peneliti melakukan dengan sangat hati-hati sehingga sedikit potensi terjadinya kesalahan. Oleh karean itu, sebelum ke lapangan peneliti sudah mengkonseptualisasikan rencana terlebih dahulu. Selain itu, melakukan konfirmabilitas, yaitu peneliti telah menyiapkan bahan-bahan yang diperlukan seperti data bahan mentah (catatan lapangan dan transkrip wawancara), hasil rekaman (dokumen dan foto), hasil analisis data dan yang terakhir transferbilitas, yaitu peneliti langsung menulis hasil laporan hasil temuan secermat mungkin yang menggambarkan konteks tempat penelitian diselenggarakan dengan mengacu pada fokus penelitian. Dengan uraian rinci ini terungkap

Analisis dalam penelitian ini menggunakan kualitatif deskriptif dengan tujuan agar dapat mendeskripsikan berbagai bentuk dan implementasi pendidikan multikultural berbasis kearifan lokal di SMA 1 Narmada. Oleh kareana itu, peneliti mengumpulkan semua data dengan segala kondisi yang ada dengan melihat fenomena-fenomena yang terjadi di sekitar lingkungan sekolah. Setelah data di lapangan terkumpul, peneliti langsung melakukan analisis untuk menghindari bertumpuknya data yang dapat mengakibatkan tereduksinya validitas dan kredibilitas data. Jenis analisis data yang dilakukan adalah analisis intraktif, yang terdiri dari tiga alur kegiatan yang berjalan secara simultan yaitu reduksi data, penyajian data, dan penarikan kesimpulan.

Dari paparan di atas maka peneliti langsung melakukan empat tahap seperti yang diungkapkan oleh Miles \& Huberman, (1994) yaitu antara lain: tahap pertama pengumpulan data, tahap kedua mereduksi data, tujuan mereduksi data ini agar data tidak bias, kemudian tahap tiga menyajikan data dan yang terahir pada tahap empat menyimpulkan atau penarikan hasil data yang sudah di verifikasi. Selama peneltian masih berlangsung, setiap kesimpulan yang ditetapkan terus menerus diverifikasi hingga benar-benar diperoleh konklusi yang valid dan kokoh. 


\section{Hasil Penelitian dan Pembahasan}

Bentuk Pendidikan Multikultural Berbasis Kearifan Lokal

Wales/Bales Sebagai Nilai Dasar Multikultural SMAN 1 Narmada

Salah satu wujud prilaku yang dikembangkan di SMA Negeri 1 Narmada adalah Perilaku peduli social Wales/Bales dan Menyama Braya. Kesadaran akan pentingnya sikap peduli sosial dalam bentuk Wales/Bales dan Manyama Braya di kalangan para siswa merupakan aspek kearifan lokal masyarakat di wilayah Narmada Lombok Barat yang kemudian mengakar pada diri siswa-siswi SMA Negeri 1 Narmada. Oleh karena itu, peserta didik di SMA Negeri 1 Narmada memiliki organisasi kesiswaan yang diluar OSIS yang memang tidak terbentuk secara resmi dan tertulis tetapi merupakan inisiatif siswa sendiri. Kegiatan mereka adalah menggalang dana untuk teman mereka yang sedang mendapatkan musibah.

Wales/Bales memiliki makna saling balas silaturahmi, kunjungan atau (kebaikan) yang terjadi karena kedekatan-persahabatan. Kemudian, Menyama Braya (menjalin tali persaudaraan) merupakan bentuk kearifan lokal yang dianut komunitas masyarakat Bali di Lombok Barat khususnya Narmada, yang menyatakan bahwa di dalam segala segi kehidupan, pada hakikatnya adalah cara mempertahankan hidup berdampingan demi membentuk harmoni, juga mengakar pada pribadi siswasiswi di SMA Negeri 1 Narmada yang berasal dari komunitas masyarakat Bali tersebut.

Berkaitan dengan proses pembinaan sikap peduli sosial siswa SMA Negeri 1 Narmada pada tataran proses pembelajaran, pada prinsipnya guru selalu berusaha untuk mendekatkan materi yang dipelajari dengan berbagai realitas atau keadaan nyata yang sementara terjadi dalam kehidupan masyarakat khususnya yang dimiliki oleh siswa. Sebagaimana yang diungkapkan oleh salah seorang Guru Pkn bahwa khusus untuk materi pembelajaran pendidikan kewarganegaraan yang memang misinya adalah mengembangkan nilai dan sikap. Maka saya sebagai guru dapat melakukan modifikasi berbagai metode pembelajaran yang disesuaikan dengan penanaman sikap peduli sosial pada diri siswa. Dengan demikian, proses pembinaan sikap peduli sosial siswa melalui pembelajaran PKn di kelas dapat meliputi segala pengalaman yang diaplikasikan guru kepada peserta didiknya (wawancara senin 04/01/2016).

Selain itu di SMA Negeri 1 Narmada juga terdapat kegiatan mengumpulkan sembako dan membagikan kepada masyarakat sekitar yang kurang mampu, menggalang dana membantu orang lain walaupun bukan bagian dari warga SMA Negeri 1 Narmada, mengadakan sumbangan buku-buku layak baca, dan masih banyak kegiatan sosial lainnya.

Selnjutnya, kegiatan imtaq setiap hari jumat di SMA Negeri 1 Narmada memiliki kontribusi dalam memberikan motivasi kepada peserta didik untuk mempelajari dan mempraktikkan aqidahnya dalam bentuk pembiasaan untuk melakukan akhlak terpuji dan menghindari akhlak tercela dalam kehidupan seharihari dan ini merupakan implikasi dari sikap peduli sosial atau wales/bales. Pembiasaan akhlak terpuji sebagai nilai inti mutikultural ini sangat penting untuk dipraktikkan dan dibiasakan oleh peserta didik baik itu dalam lingkungan sekolah, dalam kehidupan individu, bermasyarakat dan berbangsa, terutama dalam rangka mengantisipasi dampak negatif dari era globalisasi dan krisis multidimensional yang melanda bangsa dan Negara Indonesia tidak terkecuali di wilayah Narmada.

\section{Alam Takambang Jari Guru: Manifestasi Pembelajaran Berbasis Nilai Kearifan Lokal}

Prnsip pembelajaran Alam Takambang Jari Guru memberikan pemahaman bahwa kondisi Narmada yang memiliki keragaman dan keberagamaan masyarakat yang luar biasa, memiliki potensi yang besar dalam menanamkan nilai-nilai multikultural pada peserta didik. Pendidikan nilai merupakan nurani, sebagai upaya pembinaan terhadap nilai yang ada pada diri manusia dalam hal ini siswa, berkembang menjadi perilaku dan cara lembaga sekolah menanamkan karakter terhadap siswa untuk menghayati nilai-nilai dalam keberagaman budaya melalui pendekatan terhadap alam.

Sebagaimana ditegaskan lagi oleh guru wirausaha Ida bagus Widyadnyana bahwa karena keraifan lokal multikultural terintegrasi dalam mata pelajaran kewirausahaan. Maka saya dalam proses pembelajaran lebih sering membawa siswa untuk belajar di luar lingkungan sekolah, seperti ke tambak Ikan, karena di wilayah Narmada kebanyakan berprofesi sebagai peternak ikan. Hal ini untuk lebih 
mendekatkan siswa dengan realitas masyaraka. Disamping itu kami di sini di SMA 1 Narmada juga memiliki program unggulan yang bekerja sama dengan pemerintah Daerah, yaitu pengolahan sampah menjadi barang yang memiliki nilai. (W/11/01/16).

Merespon pentingnya pendidikan multikultural berbasis kearifan lokal di lingkungan sekolah, menurut sudut pandang guru, pendidikan multikultural wajib untuk dilaksanakan disekolah, karena itu merupakan amanat Ideologi. Jika kita tidak memaknainya utamanya sila ketiga, maka Indonesia bisa terpecah belah secara keseluruhan. Lebih lanjut disampaikan oleh guru agama Islam bahwa pelaksanaan pendidikan multikultural berbasis kearifan lokal bukan hanya PKn dan Pendidikan Agama saja yang harus memberikan pendidikan tersebut, tetapi juga mata pelajaran lainnya dituntut untuk melaksanakan pendidikan multikultural di sekolah terintegrasi baik secara tersurat maupun tersirat, tersurat mengandung pengertian bahwa secara jelas tercantum dalam kurikulum, sedangkan tersirat mengandung makna bahwa pembelajaran dapat dilaksanakan dengan menggandeng masyarakat sebagai mitra menanamkan nilai-nilai multikultural. (Pathiyah/18/01/16).

Proses Sosialisasi dan Internalisasi Pendidikan Multikultural Berbasis Kearifan Lokal

Gendang Beleq: Upaya Membangun

Kebersamaan dalam Perbedaan di SMA

Negeri 1 Narmada

Nilai kearifan lokal dalam interaksi masyarakat di wilayah Narmada pada khususnya dan Lombok pada umumnya berperan pula sebagai jembatan komunikasi yang menghubungkan sekolah dalam upaya menanamkan nilai-nilai multikulturalisme sehingga dapat meminimalisasi potensi konflik di lingkungan sekolah. Salah satu wujud jembatan komunikasi tersebut adalah pihak sekolah membentuk wadah untuk kelompok siswa berkegiatan di luar kegiatan belajar di kelas seperti kegiatan ekstrakulikuler berbasis kearifan lokal berupa kegiatan dibidang kesenian, yaitu Gendang Beleq. Gendang Beleq banyak memberikan pengaruh positif sebagai bentuk pengenalan dan penghargaan terhadap budaya yang semakin lama semakin luntur.

Berdasarkan wawancara dengan salah seorang Pembina Kesenian Gendang Beleq
SMA Negeri 1 Narmada, menjelaskan: Kearifan lokal yang merupakan ciri khas dari suku sasak yang harus dilestarikan salah satu caranya adalah dengan menjadikan kearifan lokal sebagai ekstrakurikuler di sekoah karena siapa lagi yang akan melestarikan kearifan lokal tersebut selain kita para penerus bangsa. Gendang beleq dapat dijadikan salah satu ekstrakulikuler di sekolah. Sebagaimana diketahui, kemajuan teknologi informasi telah berdampak luas bagi perkembangan sendi-sendi kehidupan masyarakat, termasuk dibidang seni dan budaya. (Wawancara pada tanggal 6/3/16)

Hal ini dapat dipahami bahwa musik dan kesenian gendang belek memainkan peran penting dalam memecahkan batas primordial serta meningkatkan harmoni sosial. Melalui seni, para siswa yang notabene muslim-sasak dan hindu-bali terlibat dalam suatu interaksi intensif tanpa memandang latar belakang beragam etnis dan agama.

Di sisi lain gendang beleq juga merupakan sarana dalam menanamkan nilai-nilai gotong royong, saling membantu, "mengalah" (dalam ungkapan tradisonal Sasak-lombok disebut dengan istilah saling ajinan dait saling tembung), menghormati dan menjaga perasaan orang lain, merupakan contoh pedoman untuk menjaga dan menjalin hubungan dengan sesama agar mendapatkan keselamatan, kesejahteraan, ketenangan, ketenteraman kedamaian, keselarasan, keserasian hidup. Segala hal yang menimbulkan konflik atau pertentangan diupayakan untuk dihindari dalam kehidupan sosial masyarakat Sasak. Konflik atau pertentangan dirasakan dan dipercaya akan menimbulkan ketidaknyamanan dalam menjalani hidup dan kehidupan. Bahkan dapat menimbulkan kesengsaraan serta membawa petaka.

\section{Kultur Sekolah: Pondasi Internalisasi Pendidikan Multikultural Berbasis Kearifan Lokal}

SMA Negeri 1 Narmada dalam mengimplementasikan teori dan konsep pendidikan multikultural berbasis kearifan lokal menggunakan pendekatan yang disebut "Whole School Approach". Penerapan unsur Lingkungan Sekolah (The School Estate) dalam kaitannya dengan Whole School Approach sebagaimana dijelaskan oleh Bpk Mustaanullah, bahwa: Proses pembelajaran dan proses pendidikan kita disini tidak hanya berpusat pada lokal kelas yang segi empat saja tapi lebih daripada 
itu kita sebagai pendidik disini berupaya terus melibatkan unsur-unsur yang lainnya meliputi lingkungan sekitar, masyarakat dan lain-lain dengan unsur budaya yang beragam. Hal ini kita maksudkan untuk lebih menanamkan nilai-nilai budaya mereka. (Wawancara pada tanggal 05/01/2016).

Menarik untuk dicermati disini, bahwa hal ini sesuai dengan prinsip pengembangan pendidikan multikultural, sebagaimana diungkapkan para sarjana seperti Banks \& McGee (2007) melihat pentingnya pendekatan yang melibatkan variabel-variabel utama sekolah. Variabel-variabel ini mencakup etos dan budaya sekolah, kurikulum dan pembelajaran, prosedur dan sistim evaluasi, kebijakan bahasa, dan pendekatan terhadap keragaman budaya. Di samping variabel-variabel penting di atas, kepemimpinan, visi sekolah, dan organisasi dan aktifitas kesiswaan merupakan variabel yang tidak bisa dilupakan untuk mencapai tujuan-tujuan pendidikan multikultural. Ringkasnya, semua variabel ini harus bekerja secara simultan untuk menuju satu titik di mana setiap siswa berkembang sesuai dengan potensinya dan menghargai keragaman budaya yang kompleks.

Pendekatan whole approach tersebut tercermin dalam kultur sekolah yang ada di SMA Negeri 1 Narmada. Kultur sekolah SMA Negeri 1 Narmada yang dibentuk oleh nilainilai multikulturalisme berbasis kearifan lokal pun dapat direalisasikan melalui beberapa hal seperti berikut:

Pertama, Berdoa menurut agama dan kepercayaan masing-masing sebelum pelajaran pertama dimulai dan seusai pelajaran terakhir, Kegiatan berdo'a ini dilakukan sebelum dan sesudah pelajaran berlangsung, baik ketika mata pelajaran berada di awal maupun di akhir jam pelajaran. Setiap guru masuk kelas siswa diwajibkan membuka pelajaran dengan berdo'a, hal ini dimaksudkan untuk menumbuhkan sikap religious siswa dengan lebih mendekatkan diri kepada Tuhannya, melibatkan Tuhan dalam setiap urusannya dan memohon agar ilmu yang diajarkan menjadi berkah dan proses belajar mengajar menjadi lancar. Ketika pelajaran berakhir pun siswa diwajibkan untuk menutup pelajaran dengan berdo'a.

Kedua, melibatkan elemen masyarakat sekitar sebagai patner dalam mengembangkan potensi siswa dalam memahami nilai-nilai budaya lokal. Kebersamaan warga sekolah yang secara keseluruhan berpartisipasi aktif dalam proses pembinaan baik melalui kegiatan belajar mengajar; kegiatan ekstrakurikuler; maupun pembiasaan di sekolah. Dalam hal ini yang dimaksud sumber daya manusia adalah seluruh warga sekolah yang turut berpartisipasi di dalam proses pembinaan nilai kepada siswa.

Pada dasarnya kualitas sebuah lembaga pendidikan bisa dilihat dari sejauh mana keberhasilannya dalam meningkatkan kualitas mulai dari kultur organisasi atau institusi. Peran kultur di sekolah akan sangat mempengaruhi perubahan sikap maupun perilaku dari warga sekolah. Kultur sekolah yang positif akan menciptakan suasana kondusif bagi tercapainya visi dan misi sekolah, demikian sebaliknya kultur yang negatif akan membuat pencapaian visi dan misi sekolah mengalami banyak kendala.

Selain faktor-faktor pendukung dalam proses sosialisasi dan internalisasi dalam upaya memantapkan watak multikultural berbasis kearifan lokal siswa SMA Negeri 1 Narmada, tidak dipungkiri bahwa terdapat pula faktorfaktor yang menghambat proses tersebut. Seperti yang pertama yaitu latar belakang siswa yang bermacam-macam dan kurangnya kesadaran dari diri siswa akan pentingnya nilai-nilai kearifan lokal, rasa malas dan sikap cuek serta mudah terpengaruh oleh teman untuk tidak ikut berpartisipasi dalam kegiatankegiatan di sekolah. Kedua, masih ada beberapa pihak yang tidak ikut berpartisipasi dan bekerja sama dalam pembinaan nilai-nilai multikultural berbasis kearifan lokal.

\section{Simpulan}

Berdasar hasil penelitian dan pembahasan secara keseluruhan, sehingga dapat ditarik kesimpulan bahwa hasil penelitian menunjukkan bahwa, bentuk pendidikan multikultural berbasis kearifan lokal di SMA Negeri 1 Narmada tercermin dalam kegiatan di sekolah yaitu, pertama kegiatan Imtaq dan kegiatan peduli sosial (wales/bales) sebagai nilai dasar multikultural. Kegiatan imtaq dilaksanakan untuk membentuk kecerdasan emosional dan sosial siswa serta membentuk karakter anak agar selalu menjadi pribadi yang ingat kepada Sang Pencipta. Wales bales merupakan kearifan lokal masyarakat setempat yang mengakar pada diri siswa di sekolah. Kedua, Alam takambang jari guru merupakan manifestasi 
pembelajaran berbasis kearifan lokal yang mengintegrsikan proses pembelajaran dengan melibatkan lingkungan sekolah. Ketiga, Gendang beleq sebagai bentuk pendidikan multikultural berbasis kearifan lokal yang bertujuan untuk menanamkan nilai-nilai harmonisasi dalam perbedaan. Keempat Kultur sekolah sebagai pondasi proses sosialisasi dan internalisasi nilai-nilai multikultural berbasis kearifan lokal di SMA Negeri 1 Narmada yang tercermin dalam kebiasaan siswa di sekolah antara lain, berdo'a sesuai dengan agama masing-masing dan melibatkan masyarakat sebagai patner dalam mengembangkan potensi siswa untuk memahami nilai-nilai budaya lokal. Penerapan pendidikan multikultural di sekolah dapat dilaksanakan melalui pembelajaran dikelas ataupun melalui pengkondisian kebijakan-kebijakan sekolah yang mengarah pada penciptaan lingkungan sekolah yang kondusif bagi terlaksananya pendidikan multikultural berbasis kearifan lokal. Disamping itu, yang terpenting adalah pelaksanaan pendidikan multikultural harus dapat melibatkan dan mendapat dukungan dari seluruh elemen sekolah, mulai dari kepala sekolah, guru, siswa dan warga sekolah lainnya.

Berdasarkan temuan dan hasil pembahasan di atas, terkait pendidikan multikultural berbasis kearifan lokal di SMA Negeri 1 Narmada memberi implikasi bahwa pendidikan multikultural berbasis kearifan lokal merupakan sarana yang sangat ampuh dalam mengatasi persoalan baik pada aspek diskriminasi, kesetaraan, dan yang paling penting adalah penghargaan. Artinya pendidikan mutlikultural mampu menjadi perekat dalam menumbuhkan rasa saling menghormati. Selanjutnya pendidikan multikultural yang bersumber pada nilai-nilai lokal juga memberikan dampak yang begitu besar bagi kerukunan antarsiswa yang beragam suku, agama, dan setatus sosial. Eksistensi seluruh stakeholder terutama kepala sekolah sangat ditentukan oleh sarana dan prasarana yang dapat mendukung berjalannya semua kegiatan belajar mengajar baik dalam maupun di luar kelas yang memiliki siswa yang beragam.

Berdasarkan hasil penelitian tersebut, ada beberapa saran yang dapat disampaikan oleh peneliti, yaitu: (1) konsep pendidikan multikultural belum dipahami secara holistik oleh para guru dan praktisi pendidikan, oleh sebab itu perlu dilakukan sosialisasi melalui program yang diadakan oleh Dikpora (Dinas Pendidikan Pemuda Dan Olahraga) dalam rangka mengurangi segala bentuk diskriminasi dilingkungan sekolah. (2) nilai-nilai kearifan lokal dapat dijadikan sumber pendidikan multikultural dalam proses belajar mengajar di sekolah, namun tidak semua sekolah yang menerapkannya. Dengan demikian, pihak sekolah dan Dikpora atau dinas pendidikan terkait perlu membuat kearifan lokal sebagai basis dalam pendidikan multicultural untuk diimplementasikan.

\section{Daftar Pustaka}

Arifin, A. H. A. (2012). Implementasi pendidikan multikultural dalam praksis pendidikan di indonesia. Jurnal Pembangunan Pendidikan; Fondasi dan Aflikasi. 1(1), 72-82.

Retrieved from https://journal.uny.ac.id/index.php/jpp $\mathrm{fa} /$ article/view/1052

Arifudin, I. (2007). Urgensi implementasi pendidikan multikultura di sekolah. Jurnal Pemikiran Alternatif Pendidikan, 12(2), 220-233.

Ahmad, S. (2010). Revitalisasi kearifan lokal dalam masyarakat multikultural di Kecamatan Lingsar, Lombok Barat, NTB. Jurnal Penelitian Ilmiah Analisa.XVII(02), 187-200.

Banks, J. A., \& Cherry A. McGee, C. A. (2007). Educating citizens in a multicultural society. (2nd Ed.). New York: Teacher College Press.

Dewantara, K. H. (2013). Bagian pertama. pendidikan. Pemikiran, konsepsi, keteladanan, sikap merdeka. Universitas Sarjanawiyata Tamansiswa UST-Press bekerjasama dengan Majelis Luhur Taman Siswa.

Dasrun, H. (2013). Permainan tradisional dan kearifan lokal kampung dukuh garut selatan Jawa Barat. Jurnal Academica Fakultas Ilmu Sosial Universitas Tadulako. 05(02), 1057-1070.

Mantra, I. B. (2008). Filsafat penelitian \& metode penelitian sosial. Yogyakarta: Pustaka Pelajar. 
Moleong, J. (2007). Metodologi penelitian kualitatif. Bandung: PT. Rosdakarya.

Zuriyah, N. (2011). Model pengembangan pendidikan keawarganegaraan multikultural berbasis kearifan lokal dalam fenomena sosial pasca reformasi di perguruan tinggi. Jurnal Penelitian Pendidikan, 12(2), 63-72.

Mahfud, C. (2014) Pendidikan multikultural. Yogyakarta: Pustaka Pelajar.

Miles, M. B., \&Huberman, A. M. (1994). Qualitative data analysis: an expanded source book. Thousand Oaks: Sage Publications, Inc.

Presiden Republik Indonesia. Undang-Undang Republik Indonesia Nomor 20 tahun 2003 tentang Sistem Pendidikan Nasional. 2003.

Soedigdo, D., Harysakti, A., \& Usop, T. B. (2014). Elemen-elemen pendorong kearifan lokal pada arsitektur nusantara. Jurnal Perspektif Arsitektur, 9(1), 37-47

Sugiyono. (2013). Metode penelitian pendidikan; (pendekatan kuantitatif, kulaitatif, dan $R \& D$ ). Bandung: Alfabet.

Syahid, A. (2013). Aplikasi pembelajaran berwawasan multikultural di sekolah dasar Muhammadiyah Palu. Jurnal Penelitian Ilmiah, 1(1), 109-134.

Qodariah, L. \& Armiyati, L. (2013). Nilainilai kearifan lokal masyarakat adat kampung naga sebagai alternatif sumber belajar ips smp di Tasikmalaya. Jurnal Penelitian Sosial, 12(1), 10-23.

Zamroni. (2013). Pendidikan demokrasi pada masyarakat multikultural. Yogyakarta: Ombak. 